\title{
Article \\ The Adoption of Landraces of Durum Wheat in Sicilian Organic Cereal Farming Analysed Using a System Dynamics Approach
}

\author{
Francesca Varia ${ }^{1}$ D, Dario Macaluso ${ }^{1}$, Alessandra Vaccaro ${ }^{1}$, Paolo Caruso ${ }^{2}$ and Giovanni Dara Guccione ${ }^{1, *(D)}$ \\ 1 CREA Research Centre for Agricultural Policies and Bioeconomy, via Libertà 203, 90143 Palermo, Italy; \\ francesca.varia@crea.gov.it (F.V.); dario.macaluso@crea.gov.it (D.M.); alessandra.vaccaro@crea.gov.it (A.V.) \\ 2 Department of Agriculture, Food and Environment, University of Catania, via Valdisavoia 5, \\ 95123 Catania, Italy; pcamps@libero.it \\ * Correspondence: giovanni.daraguccione@crea.gov.it
}

Citation: Varia, F.; Macaluso, D.; Vaccaro, A.; Caruso, P.; Guccione, G.D. The Adoption of Landraces of Durum Wheat in Sicilian Organic Cereal Farming Analysed Using a System Dynamics Approach. Agronomy 2021, 11, 319. https:// doi.org/10.3390/agronomy11020319

Academic Editor: Riccardo Testa

Received: 30 December 2020

Accepted: 8 February 2021

Published: 11 February 2021

Publisher's Note: MDPI stays neutral with regard to jurisdictional claims in published maps and institutional affiliations.

Copyright: (c) 2021 by the authors. Licensee MDPI, Basel, Switzerland. This article is an open access article distributed under the terms and conditions of the Creative Commons Attribution (CC BY) license (https:// creativecommons.org/licenses/by/ $4.0 /)$.

\begin{abstract}
The adoption of rare, traditional crops represents a good example of enhancing functional agrobiodiversity, not only to provide benefits for farmers but also for society as a whole. The study outlined in this paper aims to verify how and under local social-ecological conditions the combination of organic cereal farming and growing of durum wheat landraces can be profitably applied. Focusing on Sicily as one of the most developed cereal systems existing in southern Italy, the study deployed a comparison between data from the regional dataset by the Farm Accountancy Data Network (FADN) and the data provided by the Association of farmers called Simenza. Thereafter, we used a System Dynamics Approach (SDA) for a better understanding of the main drivers which will most likely affect the profitability of the system in the medium and long term. The results clearly demonstrated how the durum wheat organic system under investigation might still develop under the push of an increasing relative economic advantage between standard varieties and landraces.
\end{abstract}

Keywords: food security; biodiversity conservation; dynamic drivers; social-ecological systems; causal loop diagram

\section{Introduction}

Globally, agricultural production is undergoing marked changes because of rapid shifts in consumer demands, input costs, and increasing concerns for food security and environmental impact, especially under the current biodiversity loss and climate change scenarios [1,2]. A growing body of literature has recently addressed the specific nexus between food security and biodiversity conservation [3-5]. Many studies recognized that there exist in the world successful social-ecological systems where a sustainable integration between production and biodiversity conservation has been achieved. All such sustainable systems share the principle of enhancing functional agrobiodiversity (FAB) to reduce the reliance on synthetic inputs $[4,6]$. The adoption of traditional crops represents a good example of FAB generating multiple benefits (e.g., improved income from value-added speciality products; future adaptive capacity and resilience to disturbances) [6]. Since the utilisation of agrobiodiversity produces a flow of goods and services, which may have a market value, the generic term "genetic resources" has come into common use, highlighting that getting a return from biodiversity is possible and desirable [7]. However, there is a paucity of studies explaining how, especially in developed countries, the new biodiversity-based, social-ecological systems can actually generate desirable outcomes.

In an attempt to reduce this gap, the study outlined in this paper wishes to contribute to the debate regarding functional agrobiodiversity by presenting an individual case of social-ecological landrace system which is being developed in Sicily.

Occupying 66 per cent of the land area of the Island, the Sicilian agriculture sector is of fundamental importance for the economic development of rural communities. Durum wheat represents one of the most important crops in terms of cultivated area and the 
number of farms involved $(264,525 \mathrm{ha})$ [8]. At the same time, organic agriculture represents a widespread and consolidated strategy to combine improvement in environmental sustainability with profitability and competitiveness issues at the farm level. Statistics published by the National Information System on Organic Farming-SINAB [9] have demonstrated that, in the 2019 year, Sicily was the largest area among Italian regions for the area under organic farming, with a total of 370,622 hectares (of which 50,828 hectares under cereals, representing 15.3 per cent of the total area under cereals in Italy). This surface counted for 25.8 per cent of the total agricultural area of the region. In addition, 10,596 operators were involved; 75.0 per cent of whom were farmers, and the rest were mostly processors [9].

Sicily is also considered as one of the ten Mediterranean regional plant diversity hotspots [10-12] not only in terms of total species richness but also, and especially, for the high number of endemics (321 according to Raimondo et al. [11]).

The Sicilian plant biodiversity includes many species of crops, vegetables, orchards and wild plants for food use. For example, there are 55 ecotypes of durum wheat and bread wheat featuring great adaptability to the semiarid climate of Mediterranean areas. Moreover, in Sicily, it is possible to find a variety of agro-ecosystems with a great value of biodiversity where there exist many species, cultivars, and accessions, which are an expression of climate, environment, tradition and culture of the local agriculture [13]. Zeven [14], regarding landraces, suggested the following agronomic definition: "an autochthonous landrace is a variety with a high capacity to tolerate biotic and abiotic stress, resulting in a high yield stability and an intermediate yield level under a low input agricultural system". According to Spadaro and Negri [15], meanwhile, "landrace should be defined as a variable population, which is identifiable and usually has a local name; it lacks formal crop improvement, is characterized by a specific adaptation to the environmental conditions of the cultivation area (tolerant to the biotic and abiotic stresses of that area) and is closely associated with the uses, knowledge, habits, dialects and celebrations of the people who have developed and continue to grow it". Among Sicilian traditional crops, there are several landraces [16] of wheat which were selected and widely grown by peasants in the first half of 20th century [17] before the replacement with more productive modern cultivars began [18]. In the following decades, in fact, some specific characteristics of the locally adapted landraces, such as plant height, general late maturity, and low harvest index, limited their cultivation to a few marginal areas [19]. Their current existence is the result of the great joint conservation efforts by researchers and farmers.

Today there are 19 landraces of durum wheat (locally also called "ancient grains") [20], such as Perciasacchi, Russello and Timilia reste nere (according to SIAN-Italian National Agricultural Information System [21] the other varieties are: Biancuccia, Bidì -synonymous Margherito, Bivona, Capeiti 8, Castiglione glabro, Ciciredda, Faricello, Francesa, Gioia, Martinella, Paola, Perciasacchi, Russello, Sammartinara, Scavuzza, Scorsonera, Timilia reste bianche, Timilia reste nere and Tripolino), which have been counted in the specific Section for conservation varieties of the National Register of varieties of agricultural and vegetable species kept by the Italian Ministry of Agriculture, Food and Forestry Policies-MiPAAF (the genetic resources listed in the Register are kept under responsibility and control of public authorities; such resources are not subject to an intellectual property right, or other right or technology which can limit access or multiplication by farmers).

In this regard, it should be recalled that this specific Section was established in Italy after the importance of conservation varieties was recognized by two specific European Commission Directives. The first was the Commission Directive 2008/62/CE, which provided "for certain derogations for acceptance of agricultural landraces and varieties which are naturally adapted to the local and regional conditions and threatened by genetic erosion and for marketing of seed and seed potatoes of those landraces and varieties". The second was the Commission Directive 2009/145/EC, which provided "for certain derogations, for acceptance (in the Common Catalogue) of vegetable landraces and varieties which have been traditionally grown in particular localities and regions and are threatened by genetic erosion and of vegetable varieties with no intrinsic value for commercial crop production but developed for growing under particular conditions and for marketing of seed of those landraces and varieties". 
Thus, specific rules for the registration, certification and marketing of the seed material from these varieties were issued at Italian level (Legislative Decree No 149 of 29 October 2009 [22], in implementation of Directive 2008/62/EC; Legislative Decree No 267 of 30 December 2010 [23], in implementation of Directive 2009/145/EC).

In addition, the Law No. 194 of December 1, 2015 [24] regarding "Provisions for protection and enhancement of biodiversity of agricultural and food interest", gave farmers who produce seed varieties entered in the National register of conservation varieties, in the places where these varieties have evolved their characteristic properties, the right to sell directly and locally seeds or propagating material related to these varieties and produced on the farm, as well as the right to free trade within the National Network of Biodiversity of agricultural and alimentary interest, as governed by the above-mentioned Legislative Decrees.

All this shows that, even though value chains of "ancient grains" and conventional cultivars have common ground rules, they are distinct because of the characteristic properties of conservation varieties. The registration of these latter in the National Register for conservation varieties is free of charge and can take place by request of public bodies, scientific institutions, organisations, associations, individual farmers, after the positive opinion of the relevant Region [23].

In such a context, the non-profit association called "Simenza-Cumpagnia Siciliana Sementi Contadine" was founded in February 2016 to bring together people (farmers, breeders, processors, advisors, communicators, researchers, chefs and other stakeholders) who share an interest in protecting and enhancing the huge heritage of Sicilian agrobiodiversity, without forgetting to emphasize the regional and local traditions, knowledge, food and wine culture and even linguistic expressions (many custodian farmers, informally grouped, had started to produce landraces since years 2000; for this reason we have considered data starting from 2013).

This paper aims to explain the reasons behind the development of the organic supply chains based on the conservation and enhancement of the Sicilian landraces of durum wheat. Specifically, the core work of the research will focus on the study of the role played by Simenza in promoting an even more profitable and sustainable economic system. Lastly, a System Dynamics (SD) simulation model will be presented to represent the relationships between the most relevant determinants affecting the regional organic farming system as a whole.

The research questions that need to be answered include: What are the main drivers which affect the adoption and increasing value of the Sicilian landraces of durum wheat? How do these drivers interact with each other in influencing farm profitability? Does the return to Sicilian "ancient varieties" of durum wheat represent a win-win strategy to meet the needs of local farmers, as well as of biodiversity conservation?

This paper is structured as follows: Section 2 below will focus on the Materials and Methods used in this study. Section 3 will describe the main results, and Section 4 will outline the discussion. Findings will demonstrate that, in the current historical moment of crisis for many local economies, the Simenza association is contributing to the economic value of Sicilian landraces of durum wheat, which is increasingly recognised.

\section{Materials and Methods}

The study outlined in this paper used a mixed-method (or triangulation) $[25,26]$ based on different methodological techniques considered useful in light of the research questions.

To gain an in-depth understanding of the role of Simenza Association, a case study approach was adopted, assuming that it was most appropriate in examining the holistic and meaningful characteristics of an "event" within its real-life context $[27,28]$. The choice of using this type of empirical inquiry, moreover, appeared consonant with the research aims because the boundaries between the area of influence of Simenza and the context were fuzzy. 
In addition, because capturing changes in a transition process requires a dynamic perspective, an SD simulation approach [3,29-32] was used to manage the complexity associated with the several tangible and intangible properties of the social-economic system. The SDA is in fact a methodological tool suited to study and manage complex systems characterized by feedback mechanisms. These can be considered as interconnections describing the self-organisation of the sustainability-related system; in other words, how it changes, adapts, and reorganises itself in response to the environment, including policy and decision-making processes [33-35]. In operational terms, a Causal Loop Diagram (CLD) was drawn using the Vensim PLE 7.2a software to visualise the complex array of feedback loops in the system.

Analyses were performed by collating and processing data from official statistics at the national and regional level $[8,9,36]$. Regarding statistics sources, FADN was established in 1965 (Council Regulation EEC/79/65). It is an annual sample survey carried out in all the Members States of the European Union to monitor farms' income and business activities and to understand the impact of the measures taken under the Common Agricultural Policy. The FADN is the only source of microeconomic data based on harmonised bookkeeping principles. It is based on agricultural holdings whose size is considered commercial. The applied aims to provide representative data according to three categories: region, economic size and type of farming. The informative basis was complemented by social-economic data from a group of farms belonging to Simenza. These farms were not selected based on a real sampling technique, but the choice was necessarily limited to those which kept accounts and were available to provide data.

It should be considered that today Simenza comprises 181 firms associated, of which 129 are farms, 13 are mills, 10 are bakery, 3 are small-medium pasta-factory and the rest are another type of business (Table 1). Members are distributed throughout the Sicilian territory (Figure 1).

Table 1. Simenza members (2020).

\begin{tabular}{cc}
\hline Type of Business & Number \\
\hline Farms and livestock breeding & 129 \\
Mill & 13 \\
Pasta factory & 3 \\
Bakery & 10 \\
Seed processors & 2 \\
Hotel \& Restaurant & 8 \\
Others (chefs, bloggers, association, etc.) & 16 \\
Total & 181 \\
\hline
\end{tabular}

As far as landraces of durum wheat are concerned, data regarding yield and selling price were collected from the group of Simenza farms by means direct observations. Specifically, data came from 38 farms in total observed over the period 2013-2017 (with an average of 27 organic farms per year on a total of 137 cases from Simenza association) (Table 2). Given the difficulties in collecting costs data referred to landraces cultivation, i.e., excluding non-specific costs such as overheads, these costs were estimated from data of only the three farms which were able to provide a robust informative basis. 


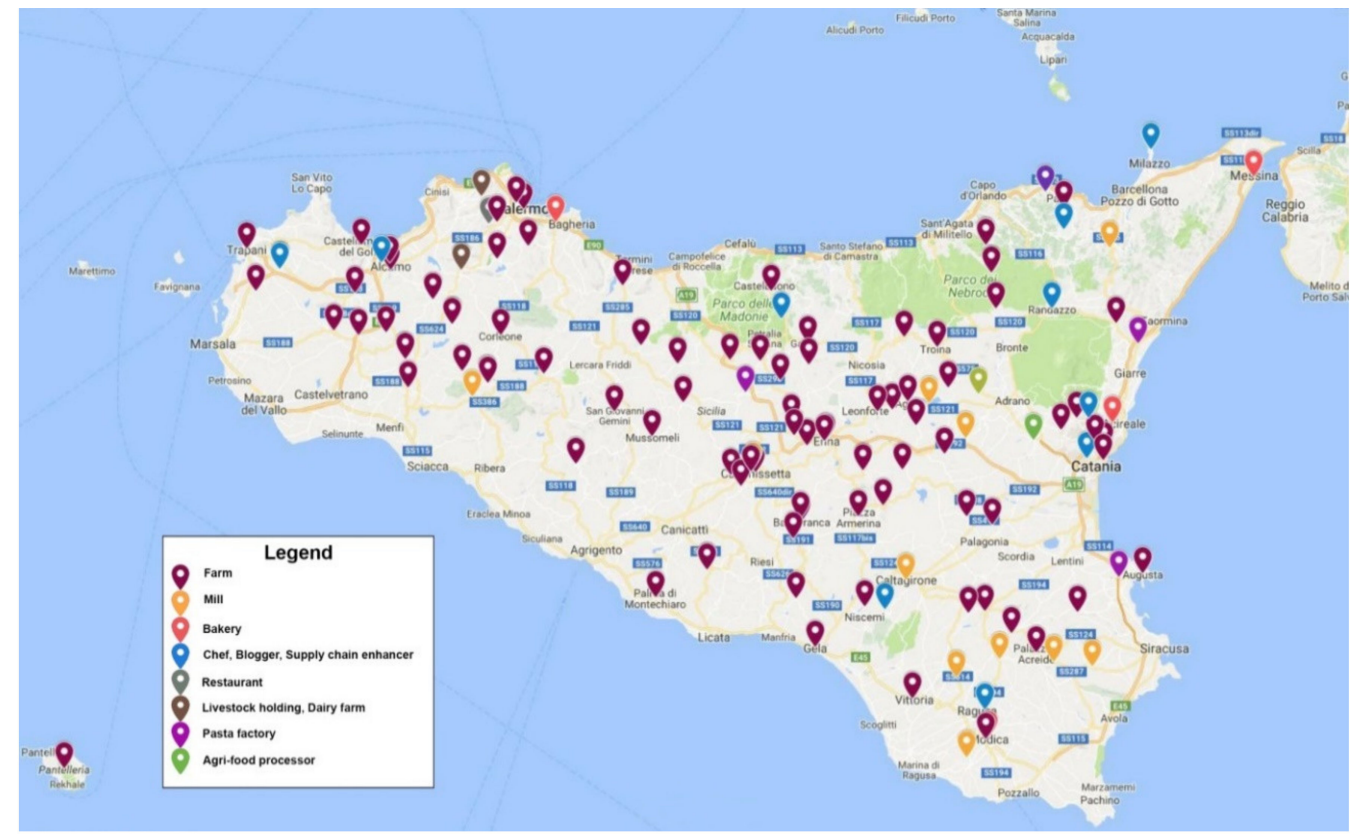

Figure 1. Map of Simenza members (2020).

Table 2. Number of observations per year.

\begin{tabular}{ccccccc}
\hline & $\mathbf{2 0 1 3}$ & $\mathbf{2 0 1 4}$ & $\mathbf{2 0 1 5}$ & $\mathbf{2 0 1 6}$ & $\mathbf{2 0 1 7}$ & Total \\
\hline FADN & 61 & 43 & 55 & 57 & 66 & 282 \\
Sicily & 34 & 34 & 34 & 15 & 20 & 137 \\
Simenza & 34 &
\end{tabular}

The data related to standard varieties were extracted from the publicly available FADN Sicily database. Specifically, data came from 129 farms observed (Figure 2) over the period 2013-2017 (with an average of 56 organic farms per year on a total of 282 observations). This informative basis included the production cost data.

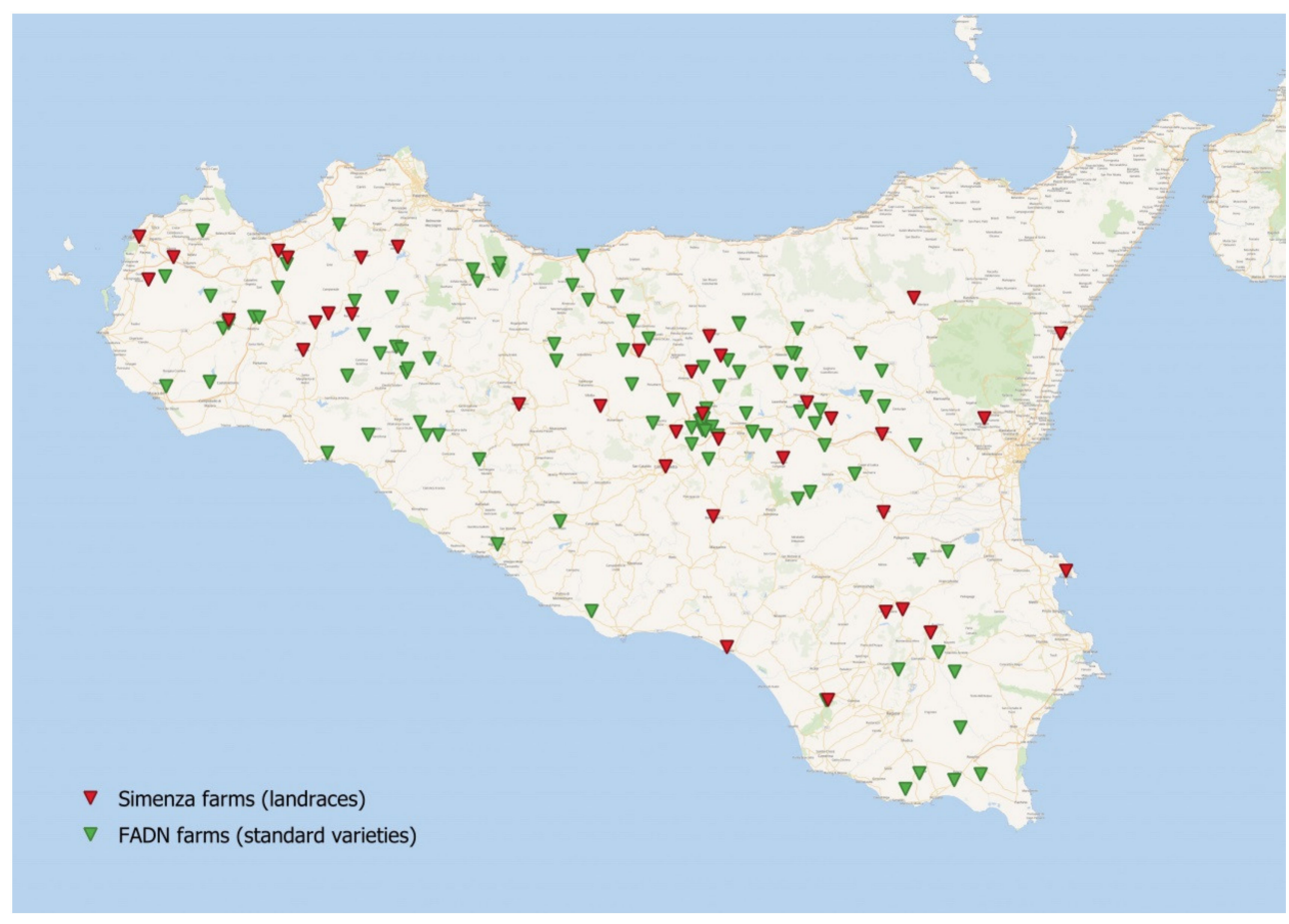

Figure 2. Map of observed farms (2020). 
To assess a possible relative economic advantage, the comparison between the two above-mentioned groups was made in terms of Operating Margin (OM). OM value was calculated, according to the Italian FADN methodology, by subtracting input costs (direct expenses, farm use, other expenses) and the labour cost (related to workers and equipment) from the Gross Output (which is equal to Gross Marketable Output plus Farm Use plus On-Farm Processed Product) an increasing between standard varieties and landraces.

The application of the SDA started by considering the influence of three different types of drivers, as shown in Table 3.

Table 3. Drivers influencing the regional landraces system.

\begin{tabular}{|c|c|c|c|c|}
\hline Driver & Sub-Drivers & Variables & Variables Value & Data Source \\
\hline \multirow{7}{*}{ Economic } & \multirow{3}{*}{ Structural features } & $\begin{array}{l}\text {-Total area under durum wheat } \\
\text { in Sicily }\end{array}$ & 264,525 ha & ISTAT, 2020 \\
\hline & & $\begin{array}{l}\text {-Total Area under organic durum } \\
\text { wheat in Sicily }\end{array}$ & 34,769 ha & SINAB, 2020 \\
\hline & & $\begin{array}{l}\text { - Total Area under organic durum } \\
\text { wheat landraces (Simenza } \\
\text { Association }\end{array}$ & 1,157 ha & $\begin{array}{c}\text { Simenza Association, } \\
2018\end{array}$ \\
\hline & \multirow{4}{*}{ Market } & -Certified landraces seed price & 1.5 euros $/ \mathrm{kg}$ & Simenza farmers, 2020 \\
\hline & & $\begin{array}{l}\text {-Price of conventional durum } \\
\text { wheat from standard varieties }\end{array}$ & $\begin{array}{l}219.62 \text { euro/ton on average } \\
\text { in the period } 2018-2019\end{array}$ & ISMEA, 2020 \\
\hline & & $\begin{array}{l}\text {-Price of organic durum wheat } \\
\text { in Sicily }\end{array}$ & $\begin{array}{l}388.81 \text { euro/ton on average } \\
\text { in the period 2018-2019 }\end{array}$ & ISMEA, 2020 \\
\hline & & $\begin{array}{l}\text {-Price of organic durum wheat } \\
\text { from landraces } \\
\text {-Import flows of durum wheat } \\
\text { —Demand of products derived from } \\
\text { landraces }\end{array}$ & $\begin{array}{l}498.12 \text { euro/ton on average } \\
\text { in the period 2013-2017 }\end{array}$ & Simenza farmers \\
\hline \multirow{6}{*}{$\begin{array}{l}\text { Agro- } \\
\text { technology }\end{array}$} & \multirow{2}{*}{$\begin{array}{l}\text { Legal } \\
\text { requirements }\end{array}$} & \multirow{2}{*}{$\begin{array}{l}\text {-Number of durum wheat landraces } \\
\text { entered in the National Register of } \\
\text { Conservation Varieties }\end{array}$} & 2 & SIAN, 2016 \\
\hline & & & 19 & SIAN, 2020 \\
\hline & \multirow{3}{*}{ Crop management } & $\begin{array}{l}\text {-Area cultivated by custodian } \\
\text { farmers }\end{array}$ & $\begin{array}{l}20 \text { ha (until 2017) } \\
755.5 \text { ha (2018) }\end{array}$ & $\begin{array}{l}\text { Decrees of the } \\
\text { Ministry of } \\
\text { Agriculture }\end{array}$ \\
\hline & & $\begin{array}{l}\text {-Average Yield of durum wheat } \\
\text { landraces }\end{array}$ & $\begin{array}{l}1.94 \mathrm{t} / \text { ha on average in the } \\
\text { period 2013-2017 }\end{array}$ & Simenza Association \\
\hline & & $\begin{array}{l}\text {-Average Yield of organic standard } \\
\text { varieties }\end{array}$ & $\begin{array}{l}2.57 \mathrm{t} / \mathrm{ha} \text { on average in the } \\
\text { period } 2013-2017\end{array}$ & FADN Sicily database \\
\hline & $\begin{array}{l}\text { Knowledge and } \\
\text { innovation transfer } \\
\text { (training, advisory } \\
\text { services, } \\
\text { information) }\end{array}$ & —Skills & Qualitative information & \\
\hline $\begin{array}{l}\text { Social } \\
\text { Quality }\end{array}$ & $\begin{array}{l}\text { Acquisition and } \\
\text { use of information } \\
\text { (word of mouth, } \\
\text { herding behaviour, } \\
\text { internet) } \\
\text { Penchant for } \\
\text { innovation } \\
\text { Efficiency and } \\
\text { transparency of } \\
\text { control systems } \\
\text { Cooperation }\end{array}$ & $\begin{array}{l}\text {-Trust of farmers in durum wheat } \\
\text { landraces }\end{array}$ & Qualitative information & \\
\hline
\end{tabular}




\section{Results}

\subsection{The Simenza Association as an Experience of Functional Agrobiodiversity}

As noted above, Simenza is a non-profit association whose main goal is to increase the value of Sicilian vegetal and animal biodiversity and particularly native wheat populations. Among its multiple and diversified activities, it worth recalling the following [37]:

- fostering cultivation, conservation, exchange, dissemination and increasing value of Sicilian genotypes, specifically those of interest for agricultural and food sectors;

- $\quad$ keeping the purity of such genotypes to reduce the risk of their extinction or genetic erosion;

- $\quad$ raising the awareness of the institutions responsible for drafting, issuing and enforcing rules and regulations in the field of agrobiodiversity;

- the registration of genotypes in the National Register of Biodiversity of Agricultural and Food Interest established by Article 3 of Law No. 194 of 1 December 2015

- the promotion and support, also in collaboration with public and private organisations, of educational and training initiatives, as well as research and development projects on the Sicilian agro-biodiversity;

- the adoption of a control system to guarantee compliance with a common product specification "from farm to fork" and all this to protect both producers and consumers (the key points of the product specification include: being a farm localised solely in Sicily, being in line with the existing regulatory framework for organic farming, growing only Sicilian ecotypes identified and kept at the Regional Experimental Station of the regional Consortium for Graniculture in Caltagirone, located in the province of Catania).

Farmers and other members to Simenza have their own legal personality and are autonomous in their commercial decisions. The so-called simenzini farmers own 2000 hectares in total.

Landraces of durum wheat are traditionally grown in rotation: 2-years cereal-forage/ legumes, with faba beans, chickpeas, grass pea, lentils, etc. and longer rotation (3-years) with typical Sicilian forage crops like sulla clover (Hedysarum coronarium L.).

When adopting landraces, farmers (simenzini or not) must basically respect the following rules:

1. making use of only certified seeds produced by custodian farmers entered in the National Register of Conservation Varieties;

2. taking all measures necessary to reduce contamination for other cereals (e.g., during the phases of threshing, transport, storage, milling and packing);

3. following a system of traceability of raw materials that end up in the food chain, as the one applied in organic farming.

Recently, along with an increasing number of landraces entered in the National Register of Conservation Varieties, there has been an exponential growth in the number of custodian farmers entitled to supply certified seeds. This trend was very encouraged by Simenza as a stakeholder in the recognition process of the requests of registration conducted at regional level (a regional Scientific and Technical Commission, which was set up in 2012, is responsible for this process).

It is worth noting that Simenza association has already achieved other considerable outcomes. First of all, it performed the geolocalisation of the landraces distinguishing their vocational areas, according to the indications left by some of the main researchers who have dealt with the subject $[18,38,39]$.

Even more importantly, Simenza played an important role in the development of a relational system which aims at bringing about social and political changes within the whole food system. It is from this perspective that the association involved various economic and social actors, to re-embed social relations within the market. In fact, the association was fundamental in supporting farmers in on-farm biodiversity and applying the principles of social agro-ecology (mainly organic, biodynamic, and regenerative farming), healthy food 
production, short supply chains, and ethics. Today around 85 per cent of the firms associated with Simenza is producing certified organic farming and some of them are adopting regenerative and biodynamic farming practices. Food security and food sovereignty appear to be the two pillars inspiring the Association. Furthermore, from a rib of Simenza, a spin-off formed by farmers, custodian farmers and processors was founded in 2019. The intent was to create a basket of products according to the provisions of the product specification. These products have to be controlled by a participatory guarantee system as a prerequisite for the release of the brand of the Association, to protect and guarantee both farmers and customers. The association in fact claims to want to "make people eat well and at a fair price". The action of Simenza has great potential to mobilize farmers, consumers and other people in forming new relations. It is presumed that there are two processes which contribute to this mechanism: the former is referred to the relational social embeddedness, the latter is linked to structural mechanisms [40] in which the behaviour and results of whole groups of people affect and promote a broader relational context, making possible many connections on the outside, as well as affecting the birth and diffusion of new networks. Among these groups of people, there are the components of the Scientific and Technical Committee inside the association, who are researchers and academics from the most important research institutions present in Sicily.

Today Simenza presents itself as a point of reference for all those who wish to improve the quality of products obtained from autochthonous certified genetic resources.

\subsection{Addressing the Complexity of the Social Economic System}

Figure 3 provides in one causal loop diagram an overview of the main feedback loops identified in the system. At the centre of the diagram, it is possible to observe two different stocks:

1. the area under organic durum wheat cultivated with standard varieties, which was related to the plethora of potential adopters and currently equal to 34,769 hectares [9];

2. the area under durum wheat cultivated with landraces from certified seed, which was associated to real adopters and currently equal to 1157 hectares, on almost 5000 hectares estimated currently sown with landraces in Sicily (data provided by Simenza Association, 2018).

As it is shown on the right of the figure, the increase of the share of adopters was linked to a general change in trust in certified landraces generating aa reinforcing loop (R1, "towards product differentiation") on the area cultivated by custodian farmers. The abandonment rate was conversely affected by another reinforcing feedback loop (R2; 'back to organic undifferentiated product'), where there was a lack of cooperation. Some Sicilian farmers consider, rationally or not, on-farm produced seed as reliable as that from certified local varieties. They fear that seeds obtained in different environmental and agronomical conditions would cause yield loss. Moreover, the costs to buy seed would be added. The adoption rate was also influenced by the virtuous accumulative effect on the trust of farmers in landraces caused by the learning process supported by the Agricultural Knowledge Innovation System (AKIS). In this way the mechanism generated an improvement in developing, specific farmers' skills to grow landraces (R3).

The comparison based on the analysis of these two different groups (Simenza association and FADN Sicily) demonstrated for landraces an average value of Operating Margin equal to 399 euro per hectare, while the same indicator for the standard varieties was about 130 euro per hectare (Figure 4). 


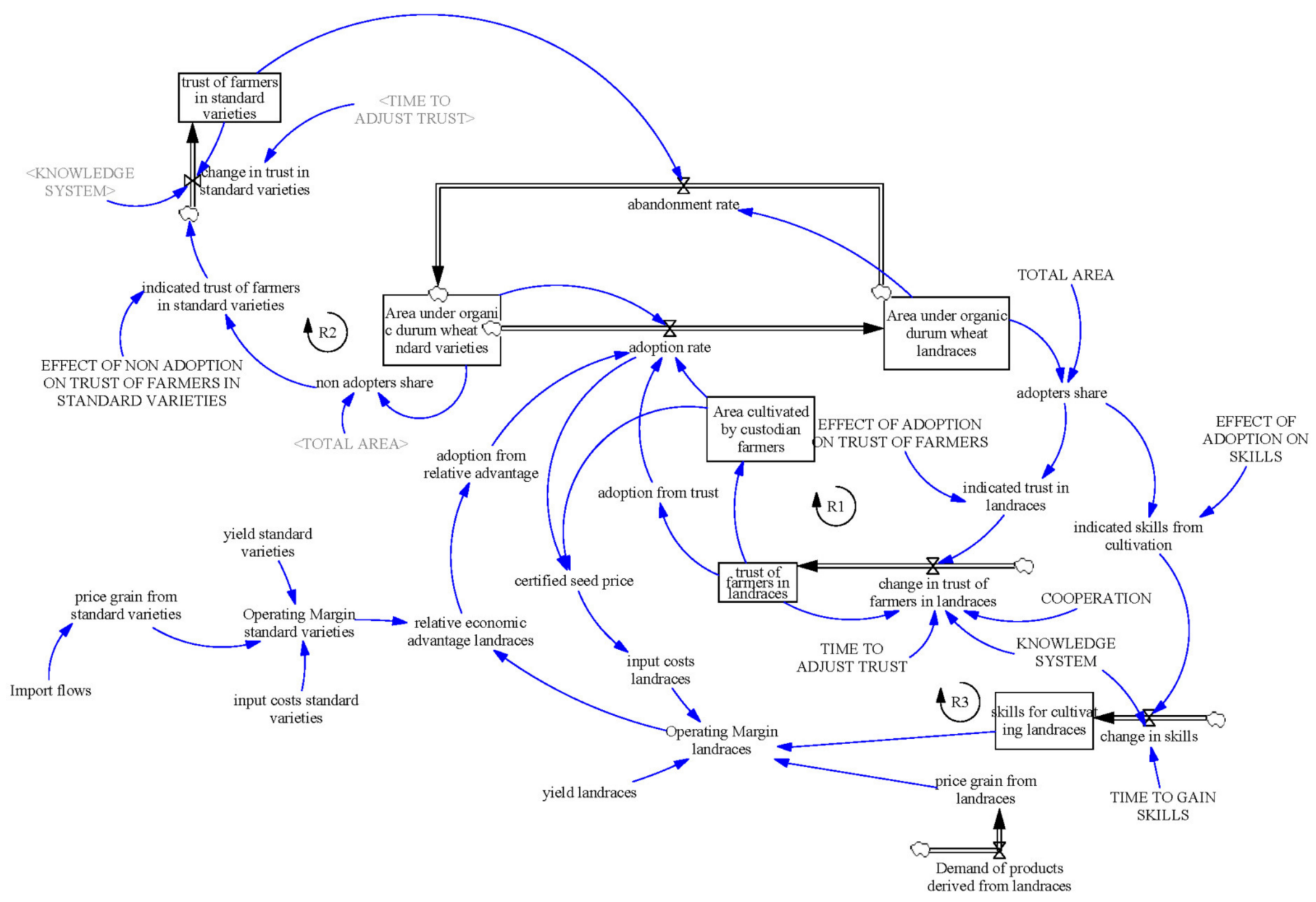

Figure 3. Causal loop diagram.

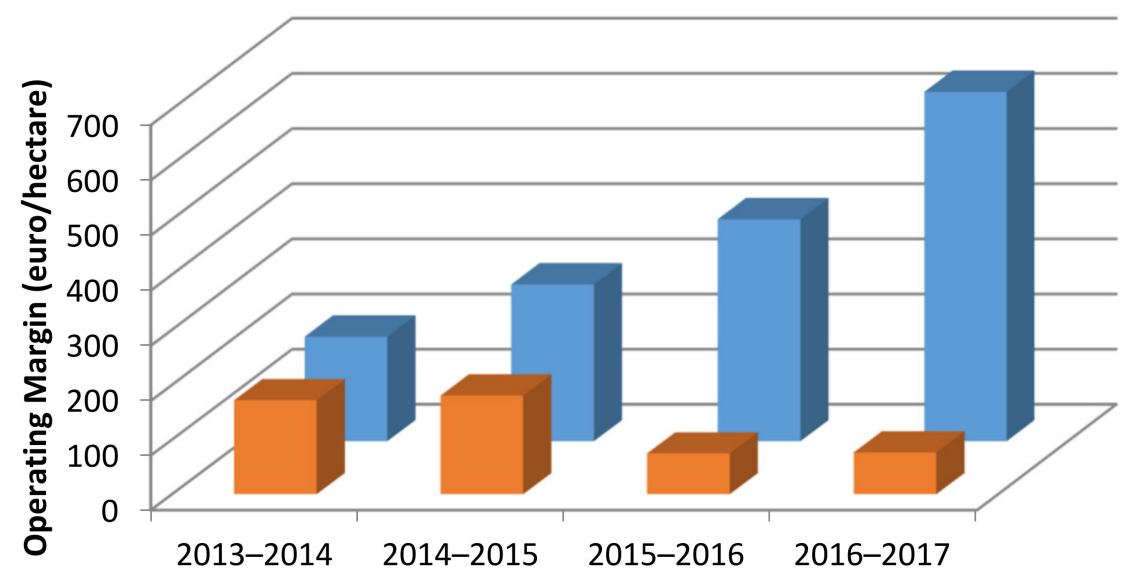

Standard durum wheat varieties Operating Margin

Ancient durum wheat varieties Operating Margin

Figure 4. Comparison based on Operating Margin (OM), (average period 2013-2017). 
This advantage (Figure 5) is due to the higher selling price of a grain of durum wheat landraces compared to the standard ones (an average of $+82 \%$ ). This sort of premium price compensates for both the higher incidence of costs $(+10 \%$, due mainly to the higher purchase price of landraces seed) and the lower yield (about $-25 \%$ ).

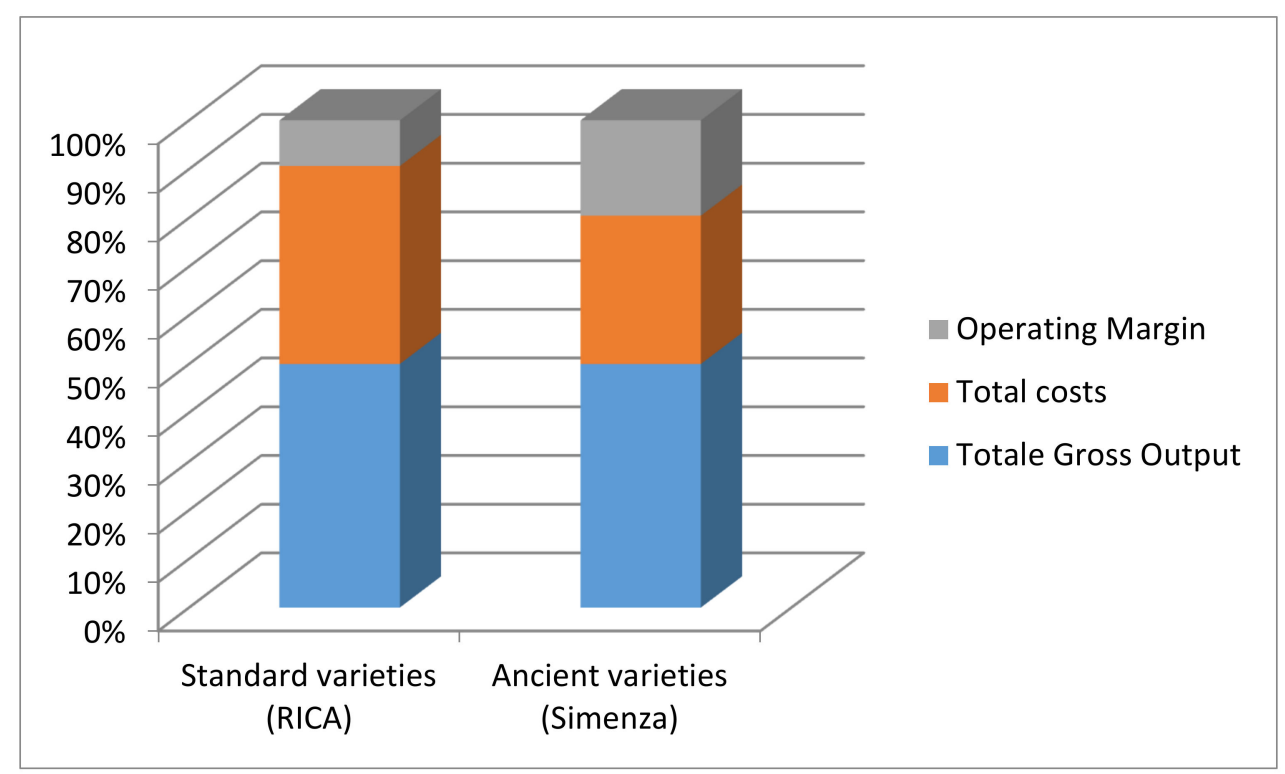

Figure 5. Comparison between economic indicators (average period 2013-2017).

Of course, this balance depends on simultaneous virtuous or vicious feedback loops which would come from the trends in consumer demand and import flows of undifferentiated wheat, respectively.

\section{Discussion}

As above mentioned, adaptability and some valuable morphological and agronomic traits, such as the resistance/tolerance to biotic and abiotic stress, make landraces an excellent genetic material to improve the resilience of wheat tackling the limited resources available in the marginal areas and in the organic agricultural systems [19]. Landraces represent the real outcomes of on-farm biodiversity even though their yield is lower than modern varieties [41], and consequently, they require more consumption of natural resources (e.g., land and water) to obtain comparable productivity.

This study has examined the perspectives of development of the social-economic system created in Sicily around durum wheat landraces by the Simenza Association. Farmers belong to this association currently cultivate with landraces around 1160 hectares, but if we wanted to project based on the number of durum wheat varieties conservation listed in the Italian National Information System [20], we would estimate a potential cultivated area of landraces that is going to reach in 2021 up to 6800 hectares. This will represent 19.5 per cent of organic durum wheat area in Sicily.

\subsection{The Main Drivers Affecting the Adoption and the Increase Value of the Sicilian Landraces of Durum Wheat}

The study has demonstrated the relevance of economic drivers along the supply chain in generating changes in the system. The latter, in fact, is constantly expanding, year after year, under the push of an increasing differential of the value of landraces (in terms of Operating Margin) in comparison with other genetic resources. This finding cannot be generalised in statistical terms, but it seems to indicate the presence of a very promising niche market. In addition, it is consistent with what observed in the Italian market of organic products from landraces, where selling prices of both raw and derived products (flour, semolina, bread and pasta) are higher than prices of undifferentiated products. 
A recent poll by the Italian Association of mills and pasta factories (Italmopa) focusing on the new bread consumption trends in Italy has also demonstrated that the organic cereal derivatives market is in "good health". The size of the market is very interesting since $84 \%$ of Italians habitually consume bread [42]. Furthermore, according to this poll, the bread consumption is expected to increase according to specific orientations: $24 \%$ of respondents preferring organic bread, 19\% bread from "ancient grain" flours and $18 \%$ bread from stone-milled flours.

\subsection{Interactions between Drivers Influencing Farm Profitability}

The balance between the fundamental drivers for farm profitability (selling price and yield) depends on simultaneous interactions with other drivers being directly relevant to the fields of agro-technology and social quality. Creating a causal loop diagram proved useful to address the complexity of the system in its broader context. It has enabled us to identify some specific leverage points at which policy instruments can be improved. For instance, what clearly emerged is the crucial importance of leveraging farmers' skills in dealing with on-farm varieties conservation. How information is generated, spread and adopted is heavily influenced by the virtuous accumulative effect on trust of farmers in landraces generated by both the Agricultural Knowledge Innovation System (AKIS) and the specific environment-oriented cooperation [43] promoted by Simenza.

\subsection{The Return to Sicilian "Ancient Varieties" of Durum Wheat}

In Sicily, the adoption of landraces of durum wheat represents a good example of FAB demonstrating that reconciling economic farmers' interests with biodiversity conservation is a viable goal. All this occurred within the context influenced by Simenza Association.

Similarly to other cases reported in the international literature [4], such social-ecological system is closely tied to smallholder-based practices, a high appreciation of social and natural capital, a strong emphasis on the engagement of key "actors" (e.g., custodian farmers, processors, advisors, communicators, researchers, and other stakeholders) in local actions for agroecological advances, as well as in social networks to promote sharing, co-creation and spreading of knowledge. The association plays a fundamental role in supporting farmers in applying the principles and rules of organic farming and on-farm biodiversity, in compliance with the current legislation. Organic farming contributes to qualifying productions making them commercially more attractive for consumers willing to pay health and wellness food [44]. Furthermore, organic farming provides basic conditions for landraces traceability, without added costs. Producing certified seed according to the European and national regulatory framework allows farmers to sell and exchange seed outside their farms. This may sound a great limitation to the landrace production system, but it is unfortunately hardly needed to prevent food fraud along the supply chain [45]. For the same reason, an effective guarantee system ensuring the identity, traceability, origin and sustainability of landraces production from certified seed to commercialisation of raw and derived products is needed.

In this context, the initiatives promoted by Simenza seem to be having positive effects on efficiency and transparency of the regional system of governance responsible for agricultural biodiversity, with benefits in terms of the better reputation of landraces and farmers' incomes.

\section{Conclusions}

This study has some limits in the analytical methodology, because of a lack of information regarding the cost structure in farms which adopted landraces. Since findings cannot be generalised in statistical terms, it deserves further investigations, ideally applying the FADN methodology to stratified probability samples of adopters and non-adopters. Further examinations will be also needed as far as some intangible variables (e.g., trust in landraces and farmers' skills, customers' perceptions) are concerned. 
Thus, the authors of this research suggest that it should be considered as an exploratory study from which to draw some insights useful for stakeholders involved in the policy and decision-making processes regarding such new social-ecological systems. The latter still need to be accompanied by specific measures, which should be jointly and harmonically drawn up and implemented by both private and public organisations. For instance, it should be better to ensure tailored solutions to spread knowledge of properties of landraces among producers and consumers, as well as to develop new skills and business models favouring $0 \mathrm{~km}$ purchases (including through reliable web platforms). Other pathways could rely on some innovative tools such as blockchain, which can unequivocally identify the seeds grown from which the flour and semolina used to make pasta, biscuits and baked goods come.

This study makes an important contribution to the relatively limited research on conservation varieties and organic farming in Italy.

Author Contributions: This paper is the result of teamwork. F.V., D.M. and G.D.G. conceived the research question. F.V., D.M. and G.D.G. conceived the research design. P.C. and D.M. analysed the data. F.V., G.D.G. and D.M. discussed the results. G.D.G., F.V. and D.M. wrote the paper while A.V. and P.C. supported in writing the paper, G.D.G. supervision. All authors have read and agreed to the published version of the manuscript.

Funding: This research was partially supported by the Italian National Rural Network 2014/2020.

Institutional Review Board Statement: Not applicable.

Informed Consent Statement: Not applicable.

Data Availability Statement: Publicly available datasets were used to extract the group of farms from FADN Sicily analysed for this study. These data can be found here: https://arearica.crea. gov.it/; further information about EU FADN methodology is available on https://ec.europa.eu/ agriculture/rica/methodology1_en.cfm. Restrictions apply to the availability of data and Article from Simenza Association. They were obtained from Simenza Association and are available from the authors with the permission of Simenza Association.

Acknowledgments: The Authors wish to greatly acknowledge prof. Salvatore Cosentino of the University of Catania and all the actors of Simenza involved in the case study for their kind availability in sharing their time, knowledge and experiences. The authors would like to thank the reviewers for their useful critical comments and suggestions to the early drafts of this manuscript.

Conflicts of Interest: The authors F.V., D.M. and A.V. declare no conflict of interest. Author P.C. is technical director of Simenza Association. Author G.D.G. is a member of the technical scientific committee of Simenza Association.

\section{References}

1. Fischer, J.; Abson, D.J.; Bergsten, A.; Collier, N.F.; Dorresteijn, I.; Hanspach, J.; Hylander, K.; Schultner, J.; Senbeta, F. Reframing the food- biodiversity challenge. Trends Ecol. Evol. 2017, 32, 335-345. [CrossRef]

2. Jiren, T.S.; Hanspach, J.; Schultner, J.; Fischer, J.; Bergsten, A.; Senbeta, F.; Hylander, K.; and Dorresteijn, I. Reconciling food security and biodiversity conservation: Participatory scenario planning in southwestern Ethiopia. Ecol. Soc. 2020, 25, 24. [CrossRef]

3. Walters, J.P.; Archer, D.W.; Sassenrath, G.F.; Hendrickson, J.R.; Hanson, J.D.; Halloran, J.M.; Vadas, P.; Alarcon, V.J. Exploring agricultural production systems and their fundamental components with system dynamics modelling. Ecol. Model. 2016, 333, 51-65. [CrossRef]

4. González-Chang, M.; Wratten, S.D.; Shields, M.W.; Costanza, R.; Dainese, M.; Gurr, G.M.; Johnson, J.; Karp, D.S.; Ketelaar, J.W.; Nboyine, J.; et al. Understanding the pathways from biodiversity to agro-ecological outcomes: A new, interactive approach. Agric. Ecosyst. Environ. 2020, 301, 107053. [CrossRef]

5. Glamann, J.; Hanspach, J.; Abson, D.J.; Collier, N.; Fischer, J. The intersection of food security and biodiversity conservation: A review. Reg. Env. Chang. 2017, 17, 1303-1313. [CrossRef]

6. ELN-FAB. Functional Agrobiodiversity: Nature Serving Europe's Farmers; ECNC-European Centre for Nature Conservation: Tilburg, The Netherlands, 2012; Available online: https:/ / ec.europa.eu/environment/nature/natura2000/platform/documents / functional_agrobiodiversity_eln-fab_publication_en.pdf (accessed on 13 December 2020).

7. Marino, D. Politiche di sviluppo locale basate sulla conservazione e la valorizzazione delle risorse genetiche vegetali. Questione Agraria 1998, 71, 97-131.

8. ISTAT. Available online: http:/ / dati.istat.it/Index.aspx?DataSetCode=DCSP_COLTIVAZIONI (accessed on 20 December 2020). 
9. SINAB. Bio in Cifre; Uffici SINAB c/o MiPAAF: Roma, Italy, 2020; Available online: www.sinab.it (accessed on 10 December 2020).

10. Médail, F.; Quézel, P. Hot-Spots Analysis for Conservation of Plant Biodiversity in the Mediterranean Basin. Ann. Mo. Bot. Gard. 1997, 84, 112-127. [CrossRef]

11. Raimondo, F.M.; Domina, G.; Spadaro, V. Checklist of the vascular flora of Sicily. Quad. Bot. Amb. Appl. 2010, 21, 189-252.

12. Bonanno, G.; Veneziano, V. New insights into the distribution patterns of Mediterranean insularendemic plants: The Sicilian islands' group. Flora 2016, 224, 230-243. [CrossRef]

13. Timpanaro, G.; Bellia, C.; Foti, V.T. Horticultural Agrobiodiversity and Potential Conservation: Case Study in Sicily, 6th ed.; Ecological Performance in a Competitive Economy: Bucharest, Romania, 2014.

14. Zeven, A. Landraces: A review of definitions and classifications. Euphytica 1998, 104, 127-139. [CrossRef]

15. Spadaro, G.; Negri, V. The European seed legislation on conservation varieties: Focus, implementation, present and future impact on landrace on farm conservation. Genet. Resour. Crop. Evol. 2013, 60, 2421-2430. [CrossRef]

16. Santamaria, P.; Ronchi, L. Varietà da conservazione in Italia: lo stato dell'arte per le specie orticole, Review n. 29_Italus Hortus 2016, 23, 29-44.

17. De Cillis, U. I Frumenti Siciliani; Stazione Sperimentale di Granicoltura “Benito Mussolini” per la Sicilia: Catania, Italy, 1942; pp. 1-323.

18. Guarnaccia, P.; Blangiforti, S.; Spina, A.; Caruso, P.; Amato, C.; Mattiolo, E.; Anastasi, U. Old Sicilian Wheat Landraces as a Tool to Optimize Organic and Low-Input Farming Systems; ICC/AISTEC 'Grains for feeding the world' Proceedings: Milan, Italy, 2015.

19. Fiore, M.C.; Mercati, F.; Spina, A.; Blangiforti, S.; Venora, G.; Dell’Acqua, M.; Lupini, A.; Preiti, G.; Monti, M.; Pè, M.E.; et al. Evaluation for the Assessment of Genetic Diversity of Wheat Landraces from Sicily. Plants 2019, 8, 116. [CrossRef] [PubMed]

20. Venora, G.; Blangiforti, S. I Grani Antichi Siciliani. Manuale Tecnico per il Riconoscimento Delle Varietà Locali Dei Frumenti Siciliani; Le Fate Editore: Ragusa, Italy, 2017.

21. SIAN. Available online: https://www.sian.it/mivmPubb/listeRicercaVarieta.do (accessed on 10 December 2020).

22. Legislative Decree, October 29 2009, no. 149. Attuazione Della Direttiva 2008/62/CE Concernente Deroghe per L'ammissione Di Ecotipi E Arieta' Agricole Naturalmente Adattate Alle Condizioni Locali E Regionali E Minacciate Di Erosione Genetica, Nonche' Per La Commercializzazione Di Sementi E Di Tuberi Di Patata A Semina Di Tali Ecotipi E Varieta'; GU Serie Generale: Rome, Italy, 2009.

23. Legislative Decree. Attuazione Della Direttiva 2009/145/Ce, Recante Talune Deroghe Per L'ammissione Di Ecotipi E Varieta' Orticole Tradizionalmente Coltivate In Particolari Localita' E Regioni E Minacciate Da Erosione Genetica, Nonche' Di Varieta' Orticole Prive Di Valore Intrinseco Per La Produzione A Fini Commerciali Ma Sviluppate Per La Coltivazione In Condizioni Particolari Per La Commercializzazione Di Sementi Di Tali Ecotipi E Varieta'; GU Serie Generale: Rome, Italy, 2011.

24. LEGGE 1 Dicembre. Disposizioni Per La Tutela e La Valorizzazione Della Biodiversità Di Interesse Agricolo E Alimentare; GU Serie Generale: Rome, Italy, 2015.

25. Bezzi, C. Il Nuovo Disegno Della Ricerca Valutativa; The New Design of Evaluative Research: Milano, Italy, 2016.

26. Denzin, N.K. Triangulation 2.0. J. Mix. Methods Res. 2012, 6, 80-88. [CrossRef]

27. Yin, R.K. Case Study Research: Design and Methods, 2nd ed.; Sage publications: Los Angeles, CA, USA, 1994.

28. Yin, R.K. Case Study Research and Applications: Design and Methods, 6th ed.; Sage publications: Los Angeles, CA, USA, 2017.

29. Forrester, J.W. The Beginning of System Dynamics; Banquet Talk at the international meeting of the System Dynamics Society: Stuttgart, Germany, 1989.

30. Fisher, D.K.; Norvell, J.; Sonka, S.; Nelson, M.J. Understanding technology adoption through system dynamics modelling: Implications for agribusiness management. Int. Food Agribus. Manag. Rev. 2000, 3, 281-296. [CrossRef]

31. Kopainsky, B.; Tröger, K.; Derwisch, S.; Ulli-Beer, S. Designing Sustainable Food Security Policies in Sub-Saharan African Countries: How Social Dynamics Over-Ride Utility Evaluations for Good and Bad. Syst. Res. Behav. Sci. 2012, 29, 575-589. [CrossRef]

32. Varia, F.; Dara Guccione, G.; Macaluso, D.; Marandola, D. System Dynamics Model to Design Effective Policy Strategies Aiming at Fostering the Adoption of Conservation Agriculture Practices in Sicily. Chem. Eng. Trans. 2017, 58, 763-768. [CrossRef]

33. Fiorani, G. System thinking, System Dynamics e Politiche Pubbliche. Ph.D. Thesis, Università degli Studi di Roma "Tor Vergata", Rome, Italy, 2009. Available online: https:/ / art.torvergata.it/retrieve/handle/2108/869/7988/Tesi\%20dottorato\%20finale.pdf (accessed on 5 December 2020).

34. Baugh Littlejohns, L.; Baum, F.; Lawless, A.; Freeman, T. The value of a causal loop diagram in exploring the complex interplay of factors that influence health promotion in a multisectoral health system in Australia. Health Res Policy Syst. 2018, 16, 126. [CrossRef]

35. Honti, G.; Dörgő, G.; Abonyi, J. Review and structural analysis of system dynamics models in sustainability science. J. Clean. Prod. 2019. [CrossRef]

36. FADN. 2019. Available online: https://arearica.crea.gov.it/report_d.php (accessed on 10 December 2020).

37. Simenza Association. Articles of the Association. Administrative documentation provided by Simenza Association. 2016.

38. Vivona, A. La Distribuzione Geografica Dei Frumenti Coltivati in Sicilia e Loro Reciproca Posizione Nella Lotta Per la Conquista Delle Superfici; Italia Agricola: 1934, Reda - Ramo; Editoriale Degli Agricoltori: Verona, Italy, 1934.

39. Perrino, P.; Hammer, K. Sicilian wheat varieties. Die Kult. 1983, 31, 227-279. [CrossRef]

40. Migliore, G.; Schifani, G.; Dara Guccione, G.; Cembalo, L. Food Community Networks as Leverage for Social Embeddedness. J. Agric. Environ. Ethics 2014, 27, 549-567. [CrossRef] 
41. Recchia, L.; Cappelli, A.; Cini, E.; Garbati Pegna, F.; Boncinelli, P. Environmental Sustainability of Pasta Production Chains: An Integrated Approach for Comparing Local and Global Chains. Resources 2019, 8, 56. [CrossRef]

42. FIRAB (The Italian Foundation for Research in Organic and Biodynamic Agriculture). CONSEMI Indagine Sulla Presenza Di Omologhe Filiere in Veneto; Pietromarchi, A., Ed.; Fondazione Italiana per la Ricerca in Agricoltura Biologica e Biodinamica: Rome, Italy, 2020.

43. Gerstlberger, W.; Urbaniec, M. Innovation in environment-oriented networks. Manag. Environ. Qual. 2011, 22, 686-704.

44. Ali, T.; Ali, J. Factors affecting the consumers' willingness to pay for health and wellness food products. J. Agric. Food Res. 2020. [CrossRef]

45. Communication from the Commission to the European Parliament, The Council, The European Economic and Social Committee and the Committee of the Regions. A Farm to Fork Strategy for a fair, Healthy and Environmentally-Friendly Food System com/2020/381 Final Brussels, 20.5.2020. Institutional document. Available online: https://eur-lex.europa.eu/legal-content/EN/ TXT/?uri=CELEX:52020DC0381 (accessed on 20 January 2021). 